\title{
Osteoprotegerin Measurement
}

National Cancer Institute

\section{Source}

National Cancer Institute. Osteoprotegerin Measurement. NCI Thesaurus. Code C116206.

The determination of the amount of osteoprotegerin present in a sample. 